\title{
Pantoea Agglomerans: Nadir Bir Erken Yenidoğan Sepsisi Etkeni
}

\author{
PantoeaAgglomerans: A Rare Cause of Early Onset Neonatal Sepsis
}

\author{
Aslı Okbay GÜNEŞ ${ }^{1}$, Fatma Güliz ATMACA ${ }^{1}$, Gonca VARDAR ${ }^{1}$, ElifÖZALKAYA ${ }^{1}$ \\ Caner YÜRÜYEN ${ }^{2}$, Hacer AKTÜRK ${ }^{3}$, Güner KARATEKİN ${ }^{1}$
}

1. Sağlık Bilimleri Ünv. Zeynep Kâmil Kadın ve Çoc. Hast. Sağlık Uygulama ve Arş. Mrk., Neonatoloji Kliniği, İstanbul, Türkiye

2. Kamu Hastaneleri Hizmetleri Başkanlı̆̆l-2, Merkez Laboratuvarl, Mikrobiyoloji Bölümü, İstanbul, Türkiye

3. Sağlık Bilimleri Ünv. Zeynep Kamil Kadın ve Çocuk Hast. Sağlık Uyg. ve Arş. Mrk., Çocuk Enfeksiyon Hast., İstanbul, Türkiye

\section{$\ddot{O Z E T}$}

Pantoea türleri Enterobacteriaceae ailesinde yer alan gram-negatif basillerdir. Yenidoğan yoğun bakım ünitelerinde nadir bir sepsis etkeni olarak tanımlanmışlar ve genellikle katater ile veya kontamine parenteral sivilarla ilişkili bulunmuşlardır. Bu yazıda, erken sepsis etkeni olarak Pantoea agglomerans ile enfekte olan preterm bir yenidoğan olgusu sunulacaktır. Pantoea agglomerans'ın nadir bir erken yenidoğan sepsis etkeni olabileceğine ve iyi bir prognoza sahip olduğuna dikkat çekmek istenmiştir.

Anahtar Kelimeler: pantoea agglomerans, erken yenidoğan sepsisi, prematürite

\section{ABSTRACT \\ Pantoea species, which are the members of Enterobac- teriaceae family are gram-negative bacilli. It is identified as a rare cause of sepsis in neonatal intensive care units and found related to catheter or contaminated parenteral fluids. In this re- port, a preterm newborn who was infected with Pantoea agglo- merans as a cause of early sepsis will be presented. In this case report, it is wanted to take attention that Pantoea agglomerans in preterm infants may be a rare cause of early neonatal sepsis and have a good prognosis.}

Keywords: pantoea agglomerans, early neonatal sepsis, prematurity

\section{GÍRIŞ}

P. agglomerans, Enterobacteriaceae ailesinde yer alan gram negatif aerob basildir; bitkilerde, toprakta ve suda bulunan çevresel mikroorganizmadır. Insanlarda genellikle travma sonrası gelişen yumuşak doku ve kemik-eklem enfeksiyonlarına neden olmakla birlikte nadiren bağışıklık sorunu olan konaklarda firsatçı sistemik enfeksiyon etkeni olabilmektedirler (1-3). Çocuk hastalarda osteomiyelit, peritonit, idrar yolu enfeksiyonu ve abse oluşumu etkeni olabildiği; çoğunlukla delici travma sonucu gelişen ya da katater ile ilişkili enfeksiyona neden olduğu bildirilmiştir ${ }^{3}$.

\section{İletişim}

Sorumlu Yazar: Uzm. Dr. Aslı Okbay GÜNEŞ

Adres: Sağlık Bilimleri Üniversitesi Zeynep Kâmil Kadın ve Çocuk Hast. Sağlık Uygulama ve Arş. Mrk., Neonatoloji Kliniği, İstanbul

Tel: +90 (546) 2413739

E-Posta: asliokbay@gmail.com

Makale Geliş: 10.06.2018

Makale Kabul: 04.12.2018

DOI: http://dx.doi.org/10.16948/zktipb.432653
Yenidoğan yoğun bakım ünitelerinde (YDYBÜ), pretermlerde nadir bir geç sepsis etkeni olarak tanımlanmışlar ve genellikle katater ile veya kontamine parenteral stvilarla ilişkili bulunmuşlardır (4). P. agglomerans'in yenidoğanlarda erken yenidoğan sepsis (EYS)'inden daha sık olarak geç başlangıçlı sepsis etkeni olarak saptandığ1 görülmüştür (4-8). Literatüre bakıldığında $P$. agglomerans'ın EYS etkeni olarak saptandığ1 olgu sunumlarına rastlanmıştır. $\mathrm{Bu}$ yazıda, EYS etkeni olarak $P$. agglomerans saptanan preterm bir yenidoğan olgu sunulacaktır.

\section{OLGU}

Sağlıklı annenin üçüncü gebelik/ikinci canlı doğumu olarak fetal distres endikasyonu ile 30.gebelik haftasında acil sezaryen ile doğurtulan bebeğe solunum sıkıntısı/bradikardisi olması üzerine canlandırma uygulanmış, respiratuar distres nedeniyle surfaktan tedavisi verilmiştir. Annenin öyküsünde perinatal enfeksiyona ya da EYS risk etmeni (erken membran yırtılması ya da kötü kokulu amniyon mayii gibi) varlığına dair herhangi bir bulgu ya da yakınmaya rastlanmamıștır. Tetkiklerinde C-reaktif protein $2.52 \mathrm{mg} / \mathrm{dl}$, lökosit $38990 / \mathrm{mm}^{3}$, trombosit $66000 / \mathrm{mm}^{3}$ saptanınca kan kültürü alınarak ampisilin ve gentamisin başlanmıştır. Íkinci gün, kan kültüründe gram-negatif üreme sinyali bildirilmesi üzerine sefotaksim tedavisine geçilmiştir. Üçüncü gün, üreme $P$. agglomerans olarak raporlanmıştır. Bakterinin MALDI-TOF MS sistemiyle (VitekMS, bioMérieux), antibiyotik duyarlılığının ise Vitek2 (bioMérieux) sistemiyle belirlendiği ve sonuçların tutarlı olduğu öğrenilmiştir. Çoğu antibiyotiğe duyarlı bulunduğundan tedaviye sefotaksim ile devam edilmiș ve tedavi 10 güne tamamlanmıștır. Kontrol trombosit ve lökosit değerleri normal, C-reaktif protein $<0.2 \mathrm{mg} / \mathrm{dl}$ (negatif) saptanmıştır. Tekrarlanan kültürlerde üreme olmamıştır. Olgu postnatal 66 . gününde anne bebek uyumu sağlanarak ünitemizden taburcu edilmiştir.

\section{TARTIŞMA}

Bu olgu sunumunda P. Agglomerans'in prematüre yenidoğanda erken sepsise neden olduğu gösterilmiştir. P. Agglomerans üremesi olan prematüre olguda etkin antibiyotik tedavisi ile tam kür sağlanmiştır.

P. agglomerans 'ın yenidoğanlarda EYS'den daha sık olarak geç başlangıçlı sepsis etkeni olarak 
saptandığ1 görülmüştür (4-8). Habsahve ark. (4) ünitelerinde ardarda $\ddot{u} c ̧$ gün içinde sepsis tanısı alan sekiz yenidoğanda sepsis etkeni olarak P. agglomerans' in ürediğini, bu salgının parenteral beslenme solüsyonu kaynaklı olduğunu ve etkenin birçok antibiyotiğe duyarlı bulunmasına rağmen antibiyotik tedavisi alan yedi olgunun kaybedildiğini rapor etmişlerdir. Tiwari ve Beriha (6) ateş ve solunum s1kıntısı nedeni ile YDYBÜ' ye yatırılan dört günlük bebekte kan kültüründe P. agglomerans ürediğini ve tedaviye iyi yanit verdiğini bildirmişlerdir. Habsahve ark. (4) olgu serisinin aksine diğer iki olgu serisinde YDYBÜ' de yatırılan ve geç başlangıçlı sepsis tanıs1 alan preterm olgularda kan kültüründe $P$. agglomerans ürediği, klinik durumlarının kötü olmasına rağmen erken tanı ve uygun tedavi ile olguların tümünün düzeldiği saptanmıştır $(5,8)$. $P$. agglomerans çok nadiren EYS etkeni olarak bildirilmiştir. E.coli gibi diğer Enterobacteriaceae üyelerinin siklıkla vertikal geçiş ile yenidoğanda hastalık yapabildikleri bilinmektedir. Benzer şekilde, insan feçesinde de bulunabilen Pantoea türleri vertikal geçiş yoluyla bulaşabilir (9). Lalas ve Erichsen (9), 35. Gebelik haftasinda doğan ve 24 saatlik erken membran yırtılması öyküsü olan bir olguda EYS etkeni olarak P. agglomerans' $\imath$ saptamışlar ve bu bakterinin vertikal geçişli bir bir EYS etkeni olabileceği bildirmişlerdir. Sengupta ve ark. (10) postnatal ikinci gününde nöbet geçiren ve tetkiklerinde trombositopeni saptanan ve kan kültüründe $P$. agglomerans üreyen preterm yenidoğan olguyu sunmuşlar ve tedaviye iyi yanıt veren olguda erken tanı ile uygun antibiyotik kullanımını önemini vurgulamışlardır.

Bizim olgu sunumumuzda, klinik ve laboratuvar pozitif sepsisi olan preterm yenidoğanda kan kültürü alındıktan sonra EYS tanısı ile ampirik olarak ampisilin ve gentamisin başlanmıştır. Postnatal ikinci gününde kan kültüründen gram negatif üreme sinyali olduğu bildirildikten sonra antibiyotik tedavisi sefotaksim olarak değiştirilmiş, postnatal üçüncü gününde kan kültüründe $P$. agglomerans üremesi saptanmıştır. Antibiyogramda $P$. agglomerans'ın ampisilin, gentamisin, piperasilin/ tazobaktam dahil çalışılan diğer tüm antibiyotiklere duyarlı saptanması üzerine tedaviye sefotaksim ile devam edilmiştir. Olguda tedaviye başarılı klinik ve laboratuvar yanıt alınmıştır. Erken sepsis etkeni olarak P. agglomerans bizim olgumuzda da gösterildiği gibi iyi prognoza sahip görünmektedir. $\mathrm{Bu}$ olgu sunumuyla risk etmeni olmayan prematüre bebeklerde bile $P$. agglomerans'in bir EYS etkeni olabileceği, erken tanı ve uygun tedavi ile başarılı bir şekilde tedavi edilebileceği vurgulanmiştır.

\section{KAYNAKLAR}

Referans1 Liberto MC, Matera G, Puccio R, LoRusso T, Colosimo E, Focà E. Six cases of sepsis caused by Pantoea agglomerans in a teaching hospital. New Microbiol 2009;32 (1):119-23.

Referans2 Duerinckx JF. Case report: subacute synovitis of the knee after a rose thorn injury: unusual clinical picture. Clin Orthop Relat Res 2008;466 (12):3138-42.

Referans3 Cruz AT, Cazacu AC, Allen CH. Pantoea agglomerans, a plant pathogen causing human disease.J Clin Microbiol 2007;45 (6):1989-92.

Referans4 Habsah H, Zeehaida M, Van Rostenberghe H, et al. An outbreak of Pantoea spp. in a neonatal intensive care unit secondary to contaminated parenteral nutrition. J Hosp Infect 2005;61 (3):213-8.

Referans5 Mahapatraa A, Dhal S, Jena PP, Mohapatra A, Dash D, Padheed A. Neonatal septicaemia due to a rare bacterium: Pantoea agglomerans (caseseries). Paediatr Infect Dis 2014;6:102-4.

Referans6 Bergman KA, Arends JP, Schölvinck EH. Pantoea agglomerans septicemia in three newborn infants. Pediatr Infect Dis J 2007;26 (5):453-4.

Referans 7 Aly NY, Salmeen HN, Lila RA, Nagaraja PA. Pantoea agglomerans bloodstream infection in preterm neonates. Med Princ Pract 2008; 17 (6):500-3.

Referans8 Tiwari S, Beriha SS. Pantoea species causing early onset neonatal sepsis: a case report. J Med Case Rep 2015; 9:188.

Referans9 Lalas KM, Erichsen D. Sporadic Pantoea agglomerans bacteremia in a near-term female: case report and review of literature. Jpn J Infect Dis 2010;63 (4):290-1.

Referans10 Sengupta M, Banerjee S, Kumar Das N, Guchhait P, Misra S. Early Onset Neonatal Septicaemia Caused by Pantoea agglomerans. J Clin Diagn Res 2016;10 (5):1-2. 